\title{
Community Participation in the Management of Wechiau Community Hippo Sanctuary, Ghana
}

\author{
Ernest Amoako-Atta \\ Department of Landscape Planning and Regional Development \\ Szent István University \\ Email: Ernestamoakoatta@gmail.com \\ Frederick Dayour \\ (Corresponding author) \\ Department of Community Development \\ University for Development studies \\ School of Tourism and Hospitality \\ University of Johannesburg, South Africa \\ Email:fdayour@uds.edu.gh \\ Samuel Ziem Bonye \\ Department of Governance and Development Management \\ University for Development Studies \\ Email: ziembonye@gmail.com \\ DOI//http://dx.doi.org/10.4314/gjds.v17i1.1
}

\begin{abstract}
Effective community participation in the management of tourism projects is advocated as a useful tool for sustaining such projects but also, as a means of empowering community members. Though this subject has received much academic attention in the broader tourism literature pertaining to other regions, the specific forms of participation relative to community-based tourism projects, the activities engaged in by community members as well as the impediments to their participation in such projects are yet to be investigated and understood in Ghana. Thus, this study aims to unpack how residents get involve in the management of the Wechiau Community Hippo Sanctuary, the specific activities they undertake as well as challenges they face in that regard. The study employed a mixedmethods research design comprising 206 surveys, six in-depth interviews and four focus
\end{abstract}


group discussions. The results show that community members participate in the project through the services they offer to guests and compliance with laid down rules regarding access and usage of the resource. Also, there was unanimity regarding the forms of participation in the project which were largely coercive and inducive in nature but also barriers which were mainly operational and structural in a nature. In dealing with operational barriers, the study recommends that the Sanctuary Management Committee should provide community members with adequate information to sidestep any possible mistrust in the management. And to address structural barriers, management should also provide training programmes to the community to enable them contribute meaningfully to issues concerning the project.

Keywords: Community Participation, Tourism, Management, Mixed-Methods, Ghana

\section{INTRODUCTION}

Ecotourism as a form of tourism is often touted for the opportunity it offers for community participation (CP) in tourism and more importantly, for nature conservation and generation of economic benefits for residents. To Asiedu (2002), ecotourism projects support and sustain the growth of rural communities but also meets the needs of ecotourists. Accordingly, unlike mass tourism, this form of tourism depends on natural environments and biodiversity such as the Wechiau Community Hippo Sanctuary (WCHSP) that are largely found in rural settings and on tourists who are also sensitive to the environment and local code of ethics (Mensah \& Adofo, 2013). Moreover, ecotourism development often relies largely on existing resources in rural areas - often associated with small scale investments and infrastructure development.

Studies have demonstrated that $\mathrm{CP}$ in ecotourism projects is vital to the sustainability of such projects (Mensah \& Adofo, 2013; Afenyo \& Amuquandoh, 2014; Eshun \& Tagoe-Darko, 2015) and could be seen as a developmental and a conservation mechanism. Drumm (1998) identifies CP in ecotourism development as the active participation of local people regarding the control of ecotourism projects within a community. Through this, tourism can encourage and support the conservation of natural attractions as long as residents derive some benefits for their sustenance. And for some advocates, the benefits related to some projects in terms of the sustenance of rural livelihoods, empowerment of local communities and the development of important infrastructure justify more community-based ecotourism development initiatives (Lea, 1988; Stronza \& Gordillo, 2008; StricklandMunro \& Moore, 2013; Lee \& Jan, 2019). However, aside from the supports advanced in favour of community-based tourism projects, there are concerns relating to 
the distribution of proceeds particularly among community members. Especially, studies by Simmons (1994) and Strickland-Munro and Moore (2013) have reported on the heterogenous character of local communities relative to different power relations which often results in the skewed distribution of attendant benefits. The works of Liu (1994) and Sandbrook and Adams (2012) revealed that as often, power holders such as the rich, elites, men, traditional leaders, and business owners among others influence and control the way and manner in which benefits from ecotourism projects are shared, often to the detriment of the 'have-nots' and downtrodden in the community.

Nonetheless, one important tenet of community-based ecotourism is that the community must have total control over tourism development in terms of its scale and activities. Yet, the political, economic and socio-cultural conditions within project communities often challenge the efforts to bring about inclusiveness in tourism development and the sharing of proceeds. This could in turn make people unenthusiastic about participation in such projects and programmes and may devise ways of sabotaging such projects (Afenyo \& Amuquandoh, 2014; Lee \& Jan, 2019) thus hindering their sustainability. To curtail this, Tosun (2000) is of the view that empowering local communities at the initial stages of tourism development allows them to effectively control such initiatives in their locale. And a way to get this done is by removing obstacles that hinder their effective participation in developmental projects. Consequently, the current study investigates the nature of participation as well as the barriers to $\mathrm{CP}$ in the WCHSP.

Studies have looked into the participation of communities in tourism projects (see Li, 2003; Tosun, 2006; Hossen, 2016; Musavengane \& Simatele, 2016; Moyo \& Tichaawa, 2017; Lee \& Jan, 2019). The works of Doxey (1975), Butler (1980) and Tosun (2000) indicate that governments rely on residents for their attention and commitment in the tourism development process before any progress can be made. This means that the participation of local communities at the initial stages of tourism development is crucial to development aims at that stage (Simmons, 1994; Tosun, 2000) particularly at the exploration and involvement stages. Accordingly, $\mathrm{CP}$ is important to circumvent doubts and misunderstandings about tourism development in local communities (Simmons, 1994; Moyo \& Tichaawa, 2017). As a result, giving local communities the chance to own and control tourism resources and also take critical decisions is believed to increase their acceptance of tourism development (D'Amore, 1983) and ultimately create a sense of obligation, feeling of ownership, and practical participation in tourism (Simpson, 2008).

Despite the growing interest and research into $\mathrm{CP}$ about the management of ecotourism projects and programmes in other parts of the world (see Stronza \& Gordillo, 2008; Strickland-Munro \& Moore, 2013), studies in Ghana (see Mensah \& 
Adofo, 2013; Afenyo \& Amuquandoh, 2014; Eshun \& Tagoe-Darko, 2015; Osumanu \& Ayamga, 2017) have largely focussed on how benefits from ecotourism projects are managed and distributed. Thus, critical aspects of active CP in communitybased tourism projects such as the forms of participation, activities engaged in by community members as well as the barriers to participation are overlooked. Therefore, the objectives of this study are to identify the activities through which community members participate in the WCHSP, the forms of participation, and barriers to their participation. The study adopts the CP models by proposed Pretty (1995), Arnstein (1971) and Tosun (1999) as the theoretical bases for the discussion of the results but with more emphasis on Tosun's model of participation. It is anticipated that this study will inform decision makers especially, the Ghana Tourism Authority, District Assemblies and other local authorities such as traditional leaders on the nature of $\mathrm{CP}$ in nature-based tourism projects in the country in terms of the forms of participation and inhibitors and how to address the weaknesses, if any. The study will provide inputs into the tourism literature as to the barriers of CP in community-based tourism projects especially within the context of Ghana.

\section{LITERATURE REVIEW}

\section{Community Participation in Tourism Development}

Local communities are, no doubt, the pivot of tourism development as they cater to the needs of guests through various tourism services: accommodation, food and beverage, information, transport and entertainment amongst others (Aref \& Gill, 2010). Accordingly, CP in tourism development is crucial (Moyo \& Tichaawa, 2017). To Meier and Saavedra (2009), participation connotes the involvement of local people and other interest groups in the development of policies and programmes that will help change their communities. Therefore, Mugenda (2009) avers that CP is critical to the success of tourism projects especially community-based ones. CP in decision-making inspires people to have confidence in the tourism industry which improves services and builds a sense of community as the hosts share common goals and aspirations about the industry. Indeed, contemporary tourism development acknowledges that a well-integrated and sustainable tourism development strategy requires the effective participation of local people in community-based tourism projects. Bramwell and Lane (2003) also assert that the involvement of local people and other interested parties in tourism planning and development helps promote sustainable development by increasing the degree of equity, efficiency and harmony.

Besides, Akama (2011) and Lee and Jan (2019) are of the position that local communities should assume control over decision-making and should be the 
ones determining how tourism resources should be used or managed. Thus, the participation of local people can inspire the formulation of effective decisions and enable more involvement from locals regarding environmental conservation (Richard \& Hall, 2002). Li (2003) and Amuquandoh (2010) underscored the point that the central idea around sustainable tourism development is for the residents of the local area to effectively participate and actually become the main drivers of the management of tourism in order to satisfy their own needs. For him, local communities are expected to organise themselves to plan and manage tourism development in their areas. For these reasons, the involvement of host communities should be encouraged and supported to aid the formulation of effective decisions, increase motivations about tourism projects and assist in implementing measures for environmental conservation and protection.

\section{Barriers to Participation}

Though CP has proved to be a useful tool for ensuring that tourism benefits both guest and host, various limitations have been sighted in the tourism literature which are discussed in this section. Tosun (2000) in a study on limits to CP, identified three broad limitations to participation in a tourism development process: operational, structural and cultural limitations. The author thinks of operational barriers as those involving the centralisation of tourism development processes, unsatisfactory coordination between parties and poor access to information by local people at the destination. Tosun (ibid) observes that it is not easy to convince government of developing nations to share powers with local authorities making public administration too bureaucratic to respond to the needs of the majority effectively. Accordingly, the lack of partnership and cohesion for effective growth within the tourism industry is well-documented (Jamal \& Getz, 1995). Besides, most local people are not fully furnished with information about tourism development thus resulting in low public involvement. Structural limitations relate to the attitudes of professionals, lack of expertise especially about CP issues, elite domination, lack of trained human resources to be able to take full control over the development process, and cost of $\mathrm{CP}$ that affect effective participation by local communities. Furthermore, cultural limitations relative to the limited capacity of poor people to effectively participate in tourism development as well as the apathy and low awareness of local communities have been reported as obstacles to participatory tourism development. Tosun (2000) argues that it is vital to strengthen local residents at the initial stage of tourism development to permit them to control tourism initiatives in their area. In his study, he recommends that a way to achieve this is by eliminating all barriers that encumber local communities' involvement in tourism. The next section discusses the theoretical models underpinning the study. 


\section{Theoretical Framework}

This study is informed by Arnstein (1971), Pretty (1995) and Tosun's (1999) models of participation (See Figure 1). Although the types of participation differ between these authors, the main aspects which differentiate between the stages within the typologies are the same. They share common ideas regarding the extent or the degree to which community members have the chance or are given the chance to decide for themselves. For instance, spontaneous $\mathrm{CP}$ in Tosun's model, emphasises the provision of full managerial responsibility and authority to the host community. This is similar to the 'degrees of citizen power' in Arnstein's model and to 'selfmobilisation' and 'interactive participation' in Pretty's model. Here, the community takes total control regarding the scale of development as well as critical decisions and the day-to-day running of the project. But, this form of participation often requires the local community to have the requisite capacity for the realisation of desired outcomes.

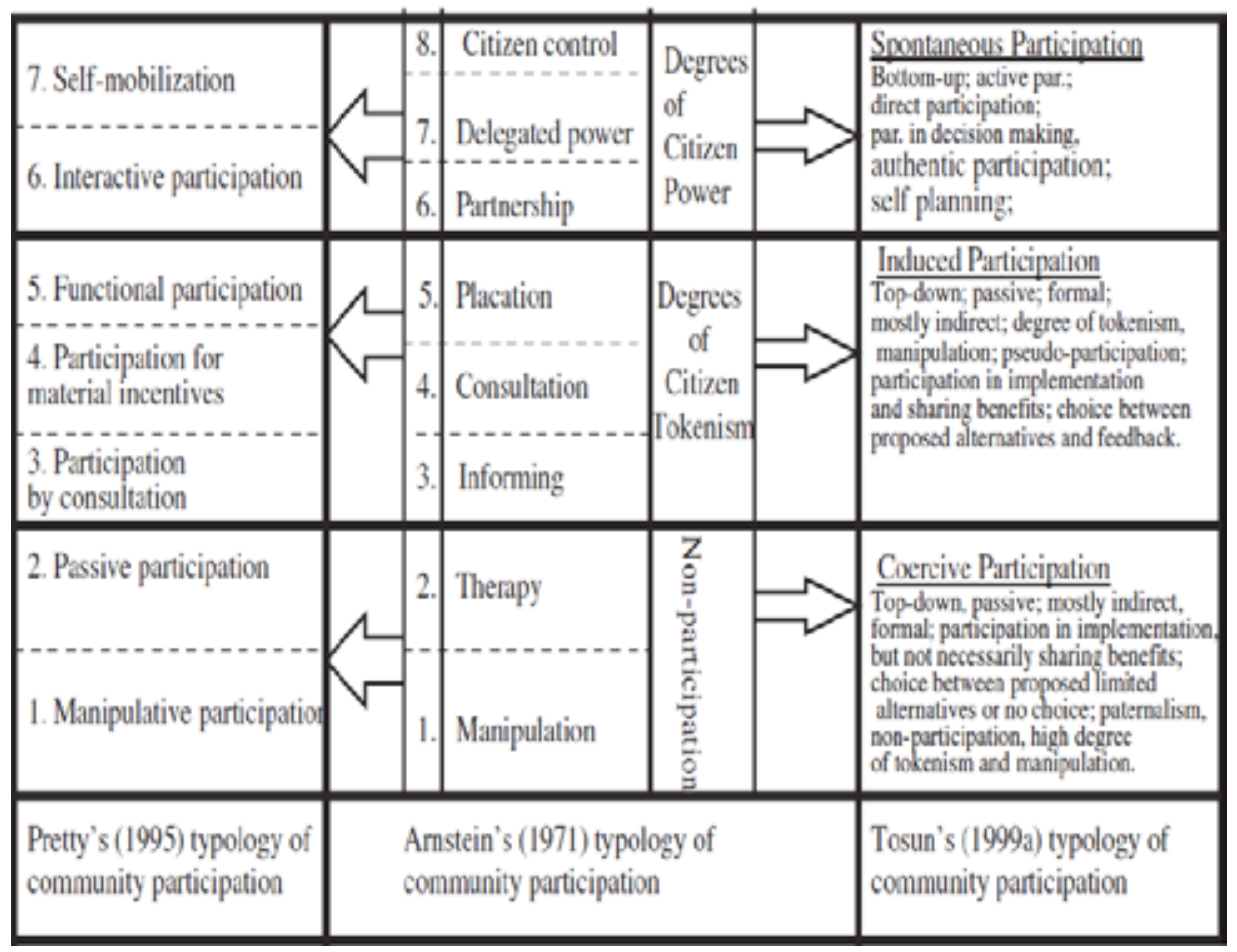

Figure 1: Normative typologies of community participation

Source: Adopted from Arnstein (1971), Pretty (1995) and Tosun (1999) 
Induced community tourism in Tosun's model, is a situation in which the host community is simply informed about tourism development projects and benefits accrued to the project and sometimes allowed to make suggestions, which are rarely implemented.

This type of participation is parallel to the degree of citizen tokenism in Arnstein's model and to functional participation by consultation or participation for material enticements in Pretty's typology. That is to say that community members only get involved because they are incentivised to participate in which case their suggestions may not be considered or used to their benefits. The community as often as not, is partly involved in the decision-making process and wields no power to make sure their views are considered for possible implementation by governments, multinational companies and non-governmental organisations among others hence inflicting a certain degree of tokenism. Induced CP is a passive and indirect form of participation most often practiced in less developed countries in which resident communities only support and may back the implementation of tourism development decisions made for their consumption rather than by them. This form of participation is often influenced by a few powerful individuals in the community.

For coercive $\mathrm{CP}$, the host community is not entirely involved in the decision-making process when compared to induced participation. However, some decisions are tailored purposely to address the basic needs of host communities in order to curb potential socio-political risks for tourists and tourism growth (Tosun, 2006). While this kind of participation is seen as a substitute for honest participation and an approach to allow power holders to foster tourism development principally to meet the desire of decision - makers, tourism operators and the tourists themselves, it is similar to manipulation and therapy in Arnstein's model but also the passive and manipulative participation in Pretty's typology (Tosun, 2006).

One important concern in tourism development is sustainability, which cannot be realised without community involvement in the process (Vincent \& Thompson, 2002). While sustainability is the core objective of $C P$, advocates of community tourism (see Vincent \& Thompson, 2002; Johannesen \& Skonhoft, 2005; Pongponrat, 2011) think that CP seeks to improve the welfare of the local community and more importantly, win their support in conservation of tourism resources (Songorwa, 1999). Thus, CP is unavoidably imperative for tourism development because most tourist attractions are found in local communities and in most cases co-exist side-by-side with local communities, for instance, in wildlife areas. 


\section{METHODOLOGY}

\section{Study Setting}

The study was undertaken in the Wa West District of the Upper West Region of Ghana. The Wa West District was carved out of Wa District in 2004 by a legislative instrument (LI 1751) under the Local Government Act 463, 1993. Wechiau is the capital of the district. The District is located in the western part of the Upper West Region, approximately between Latitudes $9^{\circ} 40^{\prime} \mathrm{N}$ and $10^{\circ} 10^{\prime} \mathrm{N}$ and also between Longitudes $2^{\circ} 20^{\prime} \mathrm{W}$ and $2^{\circ} 50^{\prime} \mathrm{W}$ (Ghana Statistical Service [GSS], 2010). It shares borders to the South with Northern Region, North by Nadowli-Kaleo District, East by Wa Municipality, South-East by Wa East and to the West by Burkina Faso. The total land area of the district is approximately 1,492.0 square kilometres (GSS, 2010).

The WCHSP is the main tourism attraction within the study area. It is a unique community-based project, protecting and preserving the wildlife and the environment of a 4okm stretch of the Black Volta River in the Upper West Region of Ghana. The river is home to one of the two remaining hippopotamus populations in Ghana, and was created into a Sanctuary by local chiefs in 1999. Since then, the project has marked successes in providing Ghanaian and international tourists with a unique and unusual eco-travel experience. The reason for selecting the WCHSP as a case for this study is twofold: 1) it is one of the many ecotourism projects in Ghana that has enjoyed a lot of support from both Government and Non-Governmental Organisations and 2) as a principle of Community Based Ecotourism Projects (CBEPs), the project is supposed to be under the management of the local people.

\section{Research Design}

Based on the paradigm of pragmatism (Johnson \& Onwuegbuzie, 2004), a concurrent (cross-sectional) mixed-methods research design was adopted for this study. By this design, both quantitative (Study A) and qualitative studies (Study B) were conducted in a single phase at the same time. The qualitative findings were essentially used to deepen the quantitative findings of the study. The target population for the study were household heads or their representatives who were above 18 years in the four communities (i.e. Wechiau, Talawona, Tokali, and Tuole) involved in the project. Household heads were selected because they play an active role in the WCHSP over the past 10-15 years and thus were chosen as the sampling units and unit of analysis (Afenyo \& Amuquandoh, 2014). Major stakeholders at the Ghana Tourism Authority (GTA), Wechiau District Assembly and Sanctuary 
Management Committee (SMC) were interviewed to understand their views on the subject.

\section{Study A - Quantitative Methods}

\section{Instrument for Data Collection}

For the quantitative dimension, structured-questionnaires were administered to household heads or their representatives in the four project communities as mentioned before. Before this, the questionnaire was pretested on 50 household heads or their representatives in Wechiau, the paramountcy of the Wa West District to ensure the questions were understandable and useful for the study. The instrument was sectioned into four main parts comprising 1) the kinds of tourism related activities the local people were engaged in, 2) the forms of participation in the project, 3) barriers to their participation and 4) socio-demographic characteristics. The forms of participation were measured on a five-point Likert scale from Strongly Agree (1) to Strongly Disagree (5) and later converted to a threepoint Likert scale for analysis. The items on the forms of participation were drawn from the literature and modified to fit the context of this study (see Tosun, 2000).

\section{Sample Size Determination and Sampling}

The sample size for the quantitative lens of the study was determined using Calculator.net, an online sample size estimator. A total of 5,135 residents aged 18 years and more constituted the population of the study communities: Wehiau (2,815), Talawona (940), Tokali (701) and Tuole (679) (see Ghana Statistical Service, 2010). Using a confidence level of $95 \%$ and a margin of error of $5 \%$, a sample size of 260 was estimated. Of this number, 206 questionnaires were found to have been fully completed after sorting and cleaning, yielding a response rate of $79 \%$.

The study used a multi-stage sampling procedure comprising both randomised and non-randomised sampling procedures. First, a purposive sampling procedure was used to select the aforementioned project communities out of 17 communities in the Wa West District. The Wechiau community was selected because it is the paramountcy and the first point of call for visitors to WCHSP. Tokali and Talawona are divisional communities that also have constant interaction with tourists. In addition, Tuole was included because it is an isolated and impoverished community along the Black Volta that either affect or is affected by the Hippo Sanctuary activities. The remaining communities in the district were not considered because they either lie remotely from the project area or are not directly involved in the management of the project. Second, a proportional allocation of the 206 sample 
among the four selected communities was done as follows: Wechiau (82), Tokali (62), Talawona (41) and Tuole (21). Finally, a random sampling of respondents based on the required stratified sample size per community was carried out.

\section{Data Analysis}

Data was analysed using SPSS version 22. This software was used in cleaning the data and generating descriptive statistics such as frequencies and percentages on respondents' background characteristics, activities engaged in by residents, the forms of participation, and the barrier to participation.

\section{Study B - Qualitative Methods}

\section{Data Collection}

For the qualitative part, In-depth Interview (IDIs) targeting institutions and Sanctuary Management Committee $(\mathrm{CMC})$ as well as Focus Group Discussion (FGDs) targeted at households were conducted. In all, six IDIs (i.e. 2 from CMC, 2 from the District Assembly and 2 from the Ghana Tourism Authority) and four FGDs, that is, one per community were conducted. Each FGD comprised between 6 and 8 respondents and lasted between 45 minutes and 1 hour. For the FGD sessions, the maximum variation sampling which allows a researcher to vary the sample based on diverse attributes such as age and sex in order to provide diversity in the data was considered in selecting participants (Saunders, Lewis, \& Thornhill, 2016). FGD and IDI guides containing open-ended questions and pre-scripted probes were used in the process of data collection (Dayour, 2019). Furthermore, conditional and spontaneous probes were not left out in carrying out these sessions in the study.

\section{Data Analysis}

For the qualitative dimension, the thematic analysis especially using deductive coding techniques was used to identify, analyse and report patterns from the interviews (Braun \& Clarke, 2006). Basically, the transcripts from the interviews were analysed using the procedure as suggested by Saunders et al. (2016): becoming familiar with the dataset; doing the coding; examining themes; recognising relationships and refining themes. Finally, the 'member check' method was used to validate the results by contacting four of the respondents, that is, one from each FGD session to validate them (Dayour, 2019). 


\section{RESULTS AND DISCUSSION}

\section{Background Characteristics of Respondents}

From Table 1, 90.3\% of the respondents were natives while the remaining 9.7\% were in-movers. The males constituted $55.8 \%$ of the sample while females were $44.2 \%$. The educational level of respondents was low as only $25.7 \%$ of respondents had primary level education, $12.6 \%$ had attained high school education, $9.2 \%$ tertiary education and $52.4 \%$ had no formal education. The age distribution of the sample was as follows: $18-24$ years (16.5\%), 25-31 years (30.6\%), 32-38 years (13.1\%), 39-45 years (14.6\%), 46-52 years (14.1\%), 53-59 years (7.8\%) and 6o+ (3.4\%).

Table 1: Socio-demographic characteristics

\begin{tabular}{|c|c|c|}
\hline Variables & Frequency & Percentage (\%) \\
\hline \multicolumn{3}{|l|}{ Residential status } \\
\hline Native & 186 & 90.3 \\
\hline In-movers & 20 & 9.7 \\
\hline \multicolumn{3}{|l|}{ Sex } \\
\hline Male & 115 & 55.8 \\
\hline Female & 91 & 44.2 \\
\hline \multicolumn{3}{|l|}{ Level of education } \\
\hline No education & 107 & 52.4 \\
\hline Primary education & 52 & 25.7 \\
\hline High School education & 26 & 12.6 \\
\hline Tertiary education & 21 & 9.3 \\
\hline \multicolumn{3}{|l|}{ Age } \\
\hline $18-24$ & 33 & 16.5 \\
\hline $25-31$ & 63 & 30.6 \\
\hline $32-38$ & 26 & 13.1 \\
\hline $39-45$ & 31 & 14.6 \\
\hline $46-52$ & 30 & 14.0 \\
\hline $53-59$ & 16 & 7.8 \\
\hline $60+$ & 7 & 3.4 \\
\hline \multicolumn{3}{|l|}{ Marital Status } \\
\hline Married & 150 & 72.6 \\
\hline Unmarried & 56 & 27.4 \\
\hline \multicolumn{3}{|l|}{ Occupation } \\
\hline Farming & 112 & 54.2 \\
\hline Petty trading & 49 & 24.0 \\
\hline Civil servant & 26 & 12.4 \\
\hline Student & 19 & 9.4 \\
\hline
\end{tabular}

Respondents who were married were in the majority $(72.6 \%)$ while those who were unmarried were $\mathbf{2 7 . 4 \%}$. Farming was the main occupation of respondents 
constituting about $54.2 \%$ followed by petty trading (24.0\%), civil servants (12.4\%) and students (9.4\%).

\section{Communities' Involvement in the WCHSP}

Residents exhibited a sense of obligation and commitment to the development and protection of the Hippo Sanctuary through various activities especially by conforming to collective norms, values, and beliefs laid down by traditional leaders and SMC for the protection of the Sanctuary. However, this behaviour is forced because those who fail to conform could get fined or exorcised from their communities thus residents try to obey accordingly (Chili, 2017). For instance, results from Table 2 show that community members played various roles in the management of the Hippo Sanctuary project some of which included respecting the laws of the sanctuary such as refraining from harvesting oysters, hunting, fishing, cutting of trees and accessing economic trees amongst others. A similar study by Osumanu and Ayamga (2017) on the role of communities in the management of Gbele Forest reserve in Ghana reported that poaching of animals and felling of trees within the forest were prohibited. A 38-year-old man from Tuole shared the following during an FGD session:

We obey the rules and regulations governing the Hippo Sanctuary. Even if your cow is missing and you go there to look for it and the tour guides get you, they will arrest and fine you, they normally think we are going there to cut firewood, so because of that we don't go there. We no longer farm closer to the place, fish, tap economic trees, hunt or cut trees for firewood....

Table 2: Activities of local communities in tourism development

\begin{tabular}{|l|c|c|}
\hline Roles & N & Percentage (\%) \\
\hline Conforming to the local laws on the sanctuary & 204 & 47.9 \\
\hline Engage in communal labour & 77 & 18.1 \\
\hline Sell souvenirs to tourist/visitors & 41 & 9.6 \\
\hline Provide tour guiding services & 29 & 6.8 \\
\hline Provide security to visitors/tourist & 24 & 5.6 \\
\hline Invite distant friends to visit the attraction & 17 & 4.0 \\
\hline Involvement in management of the attraction & 15 & 3.5 \\
\hline Provide entertainments services to tourists/visitors & 13 & 3.1 \\
\hline Host tourists/visitors & 6 & 1.4 \\
\hline Total & $426 *$ & 100 \\
\hline
\end{tabular}

*Sample size exceeded 206 because of multiple responses 
Moreover, $18.1 \%$ of the respondents participated in communal labour which resulted in the construction of a commercial lodging facility at Talawonaa to accommodate overnight tourists (Table 2). Entertaining tourists by teaching them local language, selling of local products and services such as sachet water, wild fruits and souvenirs were also found as some of the activities engaged in by the community members. Others also participated by providing tour guiding services, hosting of guest, managing the attraction and providing security. The findings suggest other ways in which residents may get involved in tourism development especially through the services they offer to guest and by conforming to laid-down rules. These forms of participation could be described as participation for material benefits (Pretty, 1995) or coercion (Chili, 2017).

From Table 3, participation in the management of the Hippo Sanctuary project could best be described as a coercive one because most respondents noted that community members were only informed about tourism development decisions after they are made by top management. About $85 \%$ of the respondents noted that community members have no say in the tourism development agenda of the community while another $91.7 \%$ mentioned that external organisations and businessmen take the leading role of providing goods and services to tourists and visitors. There was also a general consensus that the Wechiau District Assembly takes decisions on the use of revenue generated from the project - supporting the view that central governments or local authorities decide how benefits from development projects should be managed (Jamal \& Getz, 1995) often depriving local people of the opportunity to decide what such proceeds should be used for and how it should be used. To throw more light on the above, an informant stated the following during an FGD session at Wechiau:

Our leaders often tell us about tourism development decisions in this community after they are made by the SMC. Sometimes too, they come and discuss some of these development issues with us but at the end of the day our views are not taken. I can boldly say that we have no say in the tourism development agenda of the community, it is in the hands of the white men, the chiefs and elders and the sanctuary manager. So, my son, because of this, we cannot get any proper benefit from the resource... (40-year-old male indigene at Tokali).

However, interactions with members of the SMC paint a different picture about participation in the project. They argued that the SMC engages in a broader 
consultation before key decisions are made and implemented. The SMC is a composition of traditional leaders such as Tokali Naa and Wechiau Naa, Sanctuary Manager, a representative of District Assemble and the Ghana Tourism Authority and other opinion leaders. The committee makes by-laws and rules regarding access to and use of the attraction but also determines how revenue generated from the project are used. A member of the committee noted that the SMC tries to seek the opinions of community members when taking major decisions about the Sanctuary through broad-based consultation with community members. This is reflected in the words of a 67-year-old male committee member:

...as a committee in charge of managing this attraction, we cannot do so without a broad consultation with our constituents, they need to be part of the decisions we make regarding the project and we try to involve the leadership of families, opinion leaders, youth groups and women. Their views matter because, the attraction is for all of us and we need everybody to contribute to its management.

A representative of the Wechiau District Assembly maintained that:

...the facility belongs to the people of Wechiau and its surrounding communities and the management and control of the project is vested in their hands...it is a community-based project and we all know this. The District Assembly is part of the SMC and jointly takes decisions with other people regarding the management... (A 38-year-male representative of the Assembly).

Though this may have been the case, the sentiments shared by residents suggest that the SMC may be engaging in some form of placation as suggested by Arnstein (1971) or promoting participation by consultation (Pretty 1995) where residents are merely informed/consulted and views garnered without due consideration of those views for implementation. 
Table 3: Forms of $\mathrm{CP}$ in the management of the Hippo Sanctuary

\begin{tabular}{|c|c|c|c|c|}
\hline Forms of Participation & $\mathrm{N}$ & $\begin{array}{c}\text { Agree } \\
(\%)\end{array}$ & $\begin{array}{c}\text { Uncertain } \\
(\%)\end{array}$ & $\begin{array}{c}\text { Disagree } \\
(\%)\end{array}$ \\
\hline \multicolumn{5}{|l|}{ Coercive } \\
\hline $\begin{array}{l}\text { Community members are only informed } \\
\text { about tourism development decisions after } \\
\text { they are made by top management. }\end{array}$ & 206 & $\begin{array}{c}164 \\
(79.6)\end{array}$ & $\begin{array}{c}22 \\
(10.7)\end{array}$ & $\begin{array}{c}20 \\
(9.7)\end{array}$ \\
\hline $\begin{array}{l}\text { - Community members have no say in } \\
\text { the tourism development agenda of the } \\
\text { community. }\end{array}$ & 206 & $\begin{array}{c}175 \\
(85.0)\end{array}$ & $\begin{array}{c}20 \\
(9.7)\end{array}$ & $\begin{array}{c}11 \\
(5 \cdot 3)\end{array}$ \\
\hline $\begin{array}{l}\text { External organisations and business men } \\
\text { take the leading role in providing goods and } \\
\text { services to tourists and visitors. }\end{array}$ & 206 & $\begin{array}{l}189 \\
(91.7)\end{array}$ & $\begin{array}{c}10 \\
(4.9)\end{array}$ & $\begin{array}{c}7 \\
(3.4)\end{array}$ \\
\hline $\begin{array}{l}\text { Decisions taken on the use of revenue } \\
\text { generated is done by the Wechiau District } \\
\text { Assembly. }\end{array}$ & 206 & $\begin{array}{c}177 \\
(85.9)\end{array}$ & $\begin{array}{c}15 \\
(7 \cdot 3)\end{array}$ & $\begin{array}{c}14 \\
(6.8)\end{array}$ \\
\hline \multicolumn{5}{|l|}{ Spontaneous } \\
\hline $\begin{array}{l}\text { The project management team is made } \\
\text { up of representatives of all groups in the } \\
\text { community. }\end{array}$ & 206 & $\begin{array}{c}4 \\
(1.9)\end{array}$ & $\begin{array}{c}13 \\
(6.3)\end{array}$ & $\begin{array}{l}189 \\
(91.7)\end{array}$ \\
\hline $\begin{array}{l}\text { - Management decisions on project are made } \\
\text { by the whole community. }\end{array}$ & 206 & $\begin{array}{c}9 \\
(4.4)\end{array}$ & $\begin{array}{c}9 \\
(4.4)\end{array}$ & $\begin{array}{c}188 \\
(91.2)\end{array}$ \\
\hline $\begin{array}{l}\text { - Community is directly involved in providing } \\
\text { goods/services to tourists. }\end{array}$ & 206 & $\begin{array}{c}17 \\
(8.3)\end{array}$ & $\begin{array}{c}10 \\
(4.9)\end{array}$ & $\begin{array}{c}179 \\
(86.8)\end{array}$ \\
\hline $\begin{array}{l}\text { The entire community is consulted before key } \\
\text { decisions are taken. }\end{array}$ & 206 & $\begin{array}{c}4 \\
(1.9)\end{array}$ & $\begin{array}{c}12 \\
(5.8) \\
\end{array}$ & $\begin{array}{c}190 \\
(92.3)\end{array}$ \\
\hline \multicolumn{5}{|l|}{ Induced } \\
\hline $\begin{array}{l}\text { Alternative decisions are made available } \\
\text { to the community but there is no room for } \\
\text { feedback. }\end{array}$ & 206 & $\begin{array}{c}165 \\
(80.1)\end{array}$ & $\begin{array}{c}30 \\
(14.6)\end{array}$ & $\begin{array}{c}11 \\
(5 \cdot 3)\end{array}$ \\
\hline $\begin{array}{l}\text { People will have the chance to participate if } \\
\text { only they belonged to certain groups. }\end{array}$ & 206 & $\begin{array}{c}180 \\
(87.4)\end{array}$ & $\begin{array}{c}14 \\
(6.8)\end{array}$ & $\begin{array}{c}12 \\
(5.8)\end{array}$ \\
\hline $\begin{array}{l}\text { People participate because of the material and } \\
\text { financial benefits they will get in return. }\end{array}$ & 206 & $\begin{array}{c}130 \\
(63.1) \\
\end{array}$ & $\begin{array}{c}16 \\
(7.8)\end{array}$ & $\begin{array}{c}60 \\
(29.1) \\
\end{array}$ \\
\hline
\end{tabular}

The study also examined the extent to which spontaneous or citizens power or interactive participation was evident in the management of the Hippo Sanctuary. To ascertain this, four main characteristics of spontaneous participation were adapted and examined. The results from Table 3 show that the majority of respondents (91.7\%) disagreed that the project management team is made of all groups in the community while another $91.2 \%$ did not also think that management 
decisions on project are taken by all affected communities. As to community being directly involved in providing goods/services to tourists and consulted before key decisions are taken, $86.8 \%$ and $92.3 \%$ respectively did not think that was the case in the current management. Invariably, more than half of the respondents did not agree that they were spontaneously involved in the management of the project especially when it comes to decision-making and representation within the project management board. This reinforces the view that the indigenes were coercively involved in the management of the project.

The third form of $\mathrm{CP}$ which was assessed in the context of managing the Hippo Sanctuary was induced participation or tokenism. Three items reflecting this type of participation were examined among respondents. The study demonstrated that alternative decisions were made available to the communities but there was no room for feedback as noted by $80.1 \%$ of the respondents. This finding is in consonance with Moyo and Tichaawa (2017) who observed that active community involvement in tourism development, among others, is disadvantaged by poor communication between project managers and community members. Furthermore, it was also disclosed that people had the chance to participate in the management of the facility if only they belonged to certain groups of influence (87.4\%). Another interesting and notable finding was the view that people participated in the project because of the material and financial benefits associated with it (Moyo \& Tichaawa, 2017; Chili, 2017).

The findings generally point to the fact that most residents were either coercively involved or induced to participate in the management of the Hippo Sanctuary reflecting Tosun's (1999) argument on top-down participatory approaches. That is to say that those at the helm of affairs take most of the critical decisions regarding the management of the project and inform the ordinary residents and as a result, deny them the opportunity to make inputs on matters that affect them. In effect, residents only complied with by-laws and restrictions at the sanctuary because of the sanctions associated with violating them but not because there is a feeling of ownership and control over the attraction. These findings contravene Pongponrat's (2011) argument that local tourism development requires people who are affected by tourism to be involved in both the planning process and the implementation of policies and action plans. 


\section{Barriers to CP in the WCHSP}

The study further investigated the factors hindering the effective participation of residents in the project. The barriers were broadly grouped into three namely: operational, structural and cultural barriers based on Tosun's (2000) classification. Under each broad category, specific features of these barriers were adapted and assessed. Table 4 shows the types of barriers to $\mathrm{CP}$ in the management of the Sanctuary and the proportion of respondents that either agreed or disagreed with any of the barriers. Though all respondents agreed that operational, structural and cultural issues curtail their participation in the management of the Hippo Sanctuary, the level of interference of these barriers vary. Operational barriers were discovered as the major issues hindering effective participation in the project than other factors. More specifically, issues regarding the unwillingness to share power with ordinary people across all communities, centralising project management especially within Wechiau, and lack of information about the project were flagged as barriers to participation.

Here is a view shared by a 52-year-old woman during an FGD session held in Tuole:

It seems all the activities are carried out in the Wechiau community. To be frank with you my son, we don't take part in the decisionmaking process. They just come to tell us what they have decided on. Now, our farm lands are far away from where we live and it is because we were not represented. It is Tokali Naa, Wechiau Naa and the Sanctuary Manager who take all the decisions...

Also, a 43-year-old woman from Wechiau also shared her view as follows:

So far, we don't know the amount of money generated from the attraction and what it has been used for. At the same time, this manager has been the manager for so many years and he is even contesting in the assemble elections. They need to tell us how our monies are being used... 
Table 4: Barriers to $\mathrm{CP}$ in the management of the Hippo Sanctuary

\begin{tabular}{|c|c|c|c|c|}
\hline Barriers & $\mathrm{N}$ & $\begin{array}{c}\text { Agree } \\
(\%)\end{array}$ & $\begin{array}{l}\text { Uncertain } \\
\quad(\%)\end{array}$ & $\begin{array}{l}\text { Disagree } \\
(\%)\end{array}$ \\
\hline \multicolumn{5}{|l|}{ Operational } \\
\hline $\begin{array}{l}\text { - SMC's unwillingness to share } \\
\text { power of control. }\end{array}$ & 206 & $\begin{array}{l}188 \\
(91 \cdot 3)\end{array}$ & $\begin{array}{c}12 \\
(5.8)\end{array}$ & $\begin{array}{c}6 \\
(2.9)\end{array}$ \\
\hline $\begin{array}{l}\text { - Centralisation of project } \\
\text { management. }\end{array}$ & 206 & $\begin{array}{c}180 \\
(87.4) \\
\end{array}$ & $\begin{array}{c}15 \\
(7 \cdot 3)\end{array}$ & $\begin{array}{c}11 \\
(5 \cdot 3)\end{array}$ \\
\hline - Lack of information. & 206 & $\begin{array}{c}165 \\
(80.1) \\
\end{array}$ & $\begin{array}{c}25 \\
(12.1) \\
\end{array}$ & $\begin{array}{c}16 \\
(7.8)\end{array}$ \\
\hline \multicolumn{5}{|l|}{ Structural } \\
\hline $\begin{array}{l}\text { - Elite dominate the } \\
\text { management of the sanctuary. }\end{array}$ & 206 & $\begin{array}{c}153 \\
(74.2) \\
\end{array}$ & $\begin{array}{c}23 \\
(11.2) \\
\end{array}$ & $\begin{array}{c}30 \\
(15 \cdot 5)\end{array}$ \\
\hline $\begin{array}{l}\text { Poor timing of community } \\
\text { meetings. }\end{array}$ & 206 & $\begin{array}{c}130 \\
(63.1)\end{array}$ & $\begin{array}{c}44 \\
(21.4)\end{array}$ & $\begin{array}{c}32 \\
(15 \cdot 5)\end{array}$ \\
\hline $\begin{array}{l}\text { Distance to project meeting } \\
\text { location. }\end{array}$ & 206 & $\begin{array}{c}161 \\
(78.2)\end{array}$ & $\begin{array}{c}23 \\
(11.2)\end{array}$ & $\begin{array}{c}22 \\
(10.6)\end{array}$ \\
\hline $\begin{array}{l}\text { Lack of formal education to } \\
\text { allow adequate contribution to } \\
\text { decision-making. }\end{array}$ & 206 & $\begin{array}{c}122 \\
(59 \cdot 3)\end{array}$ & $\begin{array}{c}14 \\
(6.8)\end{array}$ & $\begin{array}{c}70 \\
(33.9)\end{array}$ \\
\hline \multicolumn{5}{|l|}{ Cultural } \\
\hline $\begin{array}{l}\text { - Apathy and low level of } \\
\text { awareness about the project in } \\
\text { the local community. }\end{array}$ & 206 & $\begin{array}{c}86 \\
(41.7)\end{array}$ & $\begin{array}{c}18 \\
(8.7)\end{array}$ & $\begin{array}{c}102 \\
(49.6)\end{array}$ \\
\hline - Limited capacity of local people. & 206 & $\begin{array}{c}30 \\
(14.6)\end{array}$ & $\begin{array}{c}6 \\
(2.9)\end{array}$ & $\begin{array}{l}170 \\
(82.6)\end{array}$ \\
\hline
\end{tabular}

These findings imply that the management of the Sanctuary is centralised in nature and lacks coordination between the project management and community members. The views shared by community members from Tuole, Tokali, and Wechiau confirm Tosun's (2000) description of operational barrier as one that limits effective $\mathrm{CP}$ in tourism projects. Operational barriers connote a non-decentralisation of tourism administration from the national level or local management level, preventing those at the bottom from making valuable contributions to it. Under this limitation, there is lack of co-ordination and lack of information about the project.

Moreover, structural barriers which have to do with the domination of elites in the management of the sanctuary, poor timing of community meetings, distance to meeting location and the lack of formal education to allow adequate contribution to decision-making were noted as some of the barriers to effective participation. In 
parallel, a study by Chili (2017) found that inadequate capacity among community members is a hindrance to effective community participation. As to the timing of meetings, this was not favourable to many. Either the meetings are organised during the dry season when all the active men and women have migrated to the southern part of the country or in the rainy season when they are actively engaged in farming. This according to them often breeds conflict because decisions are taken by a few influential people and imposed on every surrounding community. A 68-year-old women from Wechiau expressed her frustration during an FGD session as follows:

...the project managers and the chiefs take decisions that prevent a lot of people from participating in the project's management. They organise their meetings and we don't hear of them or even when we get to know of such meetings, the timing usually does not favour us. How can you organise meetings during the peak of the farming season when we are busy with our farm work or in the dry season when most of the youth move down south to work for money...?

The last barrier which is cultural in nature appeared not to be of much concern to community members. Respondents appear to be divided as to culturally-imposed barriers to their participation in the management of the sanctuary. For instance, nearly half (49.6\%) disagreed that the issues of apathy and low awareness about the project affected participation in the project while another $41.7 \%$ did feel that was the case. Furthermore, $82.6 \%$ of the respondents did not feel they were limited in their capacity to effectively partake in the management of the project.

\section{CONCLUSIONS AND RECOMMENDATIONS}

The study sought to examine the nature of $C P$ in the management of the WCHSP in the Wa West District of Ghana. Specifically, the study identified activities through which community members participate in the ecotourism project, the forms of participation, and barriers to their participation. The study did this by adopting three common and interrelated models on community participation (i.e. Arnstein, 1971; Pretty, 1995; Tosun, 1999) to serve as the theoretical basis for the analysis and discussion of results. The study demonstrated that community members participate or get involve in the ecotourism project through the services they offer to guests and through compliance with laid down rules, norms and values as prescribed by traditional leaders and other local authorities. Thus, their involvement through such approaches, could best be described as passive in nature since they largely 
cater to the needs of guests or compulsive because there are sanctions against flouting of prescribed rules regarding access and usage of resources within the Hippo Sanctuary.

The study found coercive and induced participations as reflective of the sentiments shared by respondents, even though, representatives from institutions and local authorities appear to disagree with this notion. But clearly, there is a disconnect between the SMC and the masses in terms of planning, decision making, and sharing of benefits from the project which needs to be addressed. Thus, the feeling of ownership as expected in community members appears to be shrouded with hopelessness and disbelieve which threatens the sustainability of the project. This view was further supported by the findings on barriers which indicate that operational and structural barriers are major interferences to effective participation in the project. Especially, the unwillingness to share power, centralisation of project management, reluctance to share information and elite domination were but some concerns raised by community members.

The paper, therefore, recommends for a shift from the use of coercive/nonparticipatory and induced/tokenism methods to more spontaneous/interactive forms of engaging community members in the WCHSP. The research revealed that there is insufficient involvement of local residents in the management process of the WCHSP, which may prevent them from receiving the needed benefits as expected. Thus, it would be prudent for the SMC, the District Assembly and Ghana Tourism Authority to encourage and integrate local people's interests into the decisionmaking process. This would help do away with issues of exclusion and inequality and ensure the sustainability of the project.

The study recommends for the elimination of all possible operational and structural barriers identified. These have negative effects on the benefits communities can derive from a tourism project (Tosun, 2000). Mathieson and Wall (1982) postulated that ecotourism projects when properly managed can exert positive benefits with limited cost to the localities in which they are situated. It is, therefore, recommended that the SMC should refrain from the centralised management approach and rather adopt an effective decentralised system in relation to the disseminating of tourism information and benefits. It has been made very clear by respondents that access to information about ecotourism activities triggers their participation and hence ensuring benefits. This, when properly done, would ensure transparency and accountability since some community members reported on issues regarding information gaps and embezzlement of tourism revenue. 


\section{RESEARCH LIMITATIONS AND FURTHER RESEARCH}

Though this study attempted addressing the objectives set, there are some limitations that provide an opportunity for future research. The study used a case study approach to assess the nature of community participation in WCHSP which obviously puts a limitation on the generalisability of the results. Thus, future studies could consider expanding the study to involved more ecotourism projects across the country to support the extrapolation of future results. Moreover, this study also adopted a deductive method of coding which relied on existing codes or themes in the literature to discuss results. Future studies may consider using an inductive approach or both to introduce more nuances and complexity into the findings.

\section{REFERENCES}

Afenyo, E. A. \& Amuquandoh F. E. (2014). Who Benefits from Community-Based Ecotourism Development? Insights from Tafi Atome, Ghana. Tourism Planning and Development, 11(2), 179-190.

Akama, J. (2011). Efficacy of Tourism as a Tool for Local Community Development: A Case Study of Mombasa, Kenya. Journal of Social Sciences, 1(1), 1-16.

Amuquandoh, F. E. (2010). Residents' Perceptions of the Environmental Impacts of Tourism in the Lake Bosomtwe Basin, Ghana. Journal of Sustainable Tourism, 18(2), 223-238.

Aref, F. \& Gill, S. S. (2010). Community Capacity Building in Tourism Development in Local Communities. Journal of Sustainable Development, 3(1): 81-90.

Arnstein, S. R. (1971). Eight Rungs on the Ladder of Citizens Participation. In S. E. Cahn \& A. B. Passet (Eds.), Citizens Participation: Effecting Community Change (pp. 69-91). Praeger Publishers.

Asiedu, A. B. (2002). Making Ecotourism More Supportive of Rural Development in Ghana. West African Journal of Applied Ecology, 3, 1-16.

Bramwell, B. \& Lane, B. (Eds.). (2003). Tourism Collaboration and Partnerships: Politics, Practice and Sustainability. Channel View Publications.

Braun, V. \& Clarke, V. (2006). Using Thematic Analysis in Psychology. Qualitative Research in Psychology, 3, 77- 101.

Butler, R. W. (1980). The Concept of Tourist Area Cycle of Evolution and Implications for Management of Resources. The Canadian Geographer, 24(1) 5-7. 
Chili, N. S. (2017). Challenges to Active Community Involvement in tourism Development at Didima Resort - A case study of Umhlwazini Community in Bergville. African Journal of Hospitality, Tourism and Leisure, 6(2), 1-15.

D’Amore, L. J. (1983). Guidelines to Planning in Harmony with the Host Community. In P. E. Murphy (Ed.), Tourism in Canada: Selected Issues and Options (pp.135-159). University of Victoria.

Dayour, F. (2019). Backpackers' Experiences with Smartphone Usage in Ghana. Anatolia: An International Journal of Tourism and Hospitality Research, 30(3), 390-403. https://doi.org/10.1080/13032917.2019.1597741.

Doxey, G. V. (1975). A Causation Theory of Visitor-Resident Irritants, Methodology, and Research Inferences. Sixth Annual Conference Proceedings of the Travel Research Association, 195-198. Travel and Tourism Research Association.

Drumm, A. (1998). New Approaches to Community-based Ecotourism Management' In K. Lindberg, M. E. Wood \& D. Engeldrum (Eds.). Ecotourism, a Guide for Planners and Managers, Vol. 2, The Ecotourism Society.

Eshun, G. \& Tagoe-Darko, E. (2015). Eco-tourism Development in Ghana: A postcolonial analysis. Development Southern Africa, 32(3), 392-406.

Ghana Statistical Service. (2010). Population and Housing Census. Ghana Statistical Service.

Hossen, M. A. (2016). Participatory Mapping for Community Empowerment. Asian Geographer, 33(2), 97-113. doi:10.1080/10225706.2016.1237370.

Jamal, B. T. \& Getz, D. (1995). Collaboration Theory and Community Tourism Planning. Annals of Tourism Research, 22(1), 186-204.

Johannesen, A. B. \& Skonhoft, A. (2005). Tourism, Poaching andWildlife Conservation: What Can Integrate Conservation and Development Projects accomplish? Resource and Energy Economics, 27, 208-216.

Johnson, R. \& Onwuegbuzie, A. (2004). Mixed Methods Research: A Research Paradigm Whose Time Has Come. Educational Researcher, 33(7), 4-26.

Lea, J. (1988). Tourism and Development in the Third World. Routledge.

Lee, T. H. \& Jan, F.-H. (2019). Can Community-Based Tourism Contribute to Sustainable Development? Evidence from Residents' Perceptions of the Sustainability. Tourism Management, 70, 368-380.

Li, W. (2003). Environmental Management Indicators for Ecotourism in China's Nature Reserves: A Case Study in Tianmushan Nature Reserve. Tourism Management, 25(5), 559-564. 
Liu, J. (1994). Pacific Islands Ecotourism: A Public Policy and Planning Guide. Honolulu, HI: Pacific Business Centre Program, University of Hawaii.

Mathieson, A. \& Wall, G. (1982). Tourism: Economic, Physical and Social Impacts. Longman Group Ltd.

Meier, M., \& Saavedra, M. (2009). Esther Phiri and the Moutawakel Effect in Zambia: An Analysis of the Use of Female Role Models in Sport-for-Development. Sport in Society, 12(9), 1158 1176. doi:10.1080/17430430903137829.

Mensah, I. \& Adofo, E. (2013). Community Participation in Ecotourism: The Case of Bobiri Forest Reserve and Butterfly Sanctuary in Ashanti Region of Ghana. American Journal of Tourism Management, 2(1), 34-42.

Moyo, S. \& Tichaawa, T. M. (2017). Community Involvement and Participation in Tourism Development: A Zimbabwe Study. African Journal of Hospitality, Tourism and Leisure, 6(1), 1-14.

Mugenda, M. (2009). Community Involvement and Participation in Tourism Development in Tanzania: A Case Study of Local Communities in Barabarani Village, MTO WA MBU, Arusha - Tanzania. Master's Thesis.

Musavengane, R. \& Simatele, D. M. (2016). Community-based Natural Resource Management: The Role of Social Capital in Collaborative Environmental Management of Tribal Resources in KwaZulu-Natal, South Africa. Development Southern Africa, 33(6), 806-821. doi:10.1080/0376835X.2016.1231054

Osumanu, I. K. \& Ayamga, S. A. (2017). Collaboration and Partnership in Forest Conservation: The Role of Communities in the Management of the Gbele Reserve in North-Western Ghana. Ghana Journal of Geography, 9(2), 91-124.

Pongponrat, K. (2011). Participatory Management Process in Local tourism Development: A Case Study on Fisherman Village on Samui Island, Thailand. Asia Pacific Journal of Tourism Research, 16(1), 57-73.

Pretty, J. N. (1995). Participatory Learning for Sustainable Agriculture. World Development, 23(8), 1247-1263.

Richard, G. \& Hall, D. (2002). Tourism and Sustainable Community Development. Rogerson.

Sandbrook, C. \& Adams, W. M. (2012). Accessing the Impenetrable: The Nature and Distribution of Tourism Benefits at a Ugandan National Park. Society \& Natural Resources: An International Journal, 25(9), 915-932.

Saunders, M., Lewis, P. \& Thornhill, A. (2016). Research Methods for Business Students (7th ed.). Pearson Education Limited. 
Simmons, D. G. (1994). Community Participation in Tourism Planning. Tourism Management, 15(2), 98-104.

Simpson, M. C. (2008). An Integrated Approach to Assessing the Impacts of Tourism on Community Development and Sustainable Livelihoods. Community Development Journal, 44(2) 1-23.

Songorwa, A. N. (1999) Community-Based Wildlife Management in Tanzania: Are the Communities Interested? World Development, 27(12), 2061-2079.

Strickland-Munro, J. \& Moore, S. (2013). Indigenous involvement and benefits from tourism in protected areas: A study of Purnululu National Park and Warmun Community, Australia. Journal of Sustainable Tourism, 21(1), 26-41.

Stronza, A. \& Gordillo, J. (2008). Community views of ecotourism. Annals of Tourism Research, 35(2), 448-468.

Tosun, C. (1999). An Analysis of Contribution of International Inbound Tourism to the Turkish Economy. Tourism Economics, 5(3), 217-251.

Tosun, C. (2000). Limits to Community Participation in the Tourism Development Process in Developing Countries. Tourism Management 21, 613-633.

Tosun, C. (2006). Expected Nature of Community Participation in Tourism Development. Tourism Management, 27, 493-504.

Vincent, V. \& Thompson, W. (2002). Assessing Community Support and Sustainability for Ecotourism Development. Journal of Travel Research, 41(2), 153-160. 